\title{
Analisis Pendapatan Usaha Agroindustri Minyak Kelapa Murni oleh Kelompok Wanita Tani Fau'ana di Desa Taekas
}

Antonius Bana ${ }^{a}$

${ }^{a}$ Fakultas Pertanian, Universitas Timor, Kefamenanu, TTU - NTT, Indonesia.

\section{Article Info}

\section{Article history:}

Received 8 September 2018

Received in revised form 16 Oktober 2018

Accepted 27 Oktober 2018

DOI:

https://doi.org/10.32938/ag.v3i4.432

\section{Keywords:}

Analisis

Pendapatan

Agroindustri

VCO

Fau'ana

\section{Abstrak}

Agroindustri adalah bagian dari agribisnis yang memproses dan mentransformasikan hasil pertanian menjadi barang setengah jadi yang langsung dipakai dan bahan agroindustri yang digunakan dalam proses produksi selanjutnya. Pengembangan agribisnis kelapa berperan penting untuk peningkatan produktivitas dan sekaligus peningkatan pendapatan petani. Penelitian ini bertujuan untuk mengetahui 1) proses pembuatan minyak kelapa murni; 2) pendapatan agroindustri minyak kelapa murni pada kelompok wanita tani Fau,ana di Desa Taekas Kecamatan Miomaffo Timur Kabupaten TTU. Penelitian dilaksanakan di Desa Taekas Kecamatan Miomaffo Timur Kabupaten TTU sejak bulan November sampai Desember 2017. Penentuan pemilihan sampel dilakukan secara sensus yaitu seluruh anggota kelompok wanita tani Fau'ana dengan demikian total pengusaha atau pelaku yang di ambil sebagai sampel sebanyak 20 orang. Untuk mengetahui gambaran usaha minyak kelapa murni digunakan metode analisis deskriptif kualitatif. Untuk mengetahui pendapatan digunakan analisis pendapatan. Hasil penelitian ini menunjukkan bahwa agroindustri minyak kelapa murni yang dilaksanakan di Desa Taekas masih dilakukan secara alami, tanpa menggunakan alat modern, secara umum tahapan kegiatan meliputi persiapan alat dan bahan, proses pembuatan, dan pemasaran. Total biaya produksi yang dikeluarkan oleh petani selama satu tahun sebesar Rp4.865.750,00 sedangkan total produksi minyak kelapa murni sebesar 784 botol, sehingga menghasilkan total penerimaan sebesar Rp19.600.000,00. Total pendapatan agroindustri minyak kelapa murni sebesar Rp14.734.250,00 dengan rata-rata pendapatan sebesar Rp1.227.850,00 per bulan.

\section{Pendahuluan}

Indonesia merupakan salah satu negara yang kaya akan jenis tanaman obatobatan yang diproduksi secara tradisional. Salah satu tanaman di Indonesia yang banyak menghasilkan manfaat yaitu tanaman kelapa (Cocos nucifera L.), berdasarkan data yang ada, terdapat 11 jenis tanaman perkebunan yang dibudidayakan oleh Rakyat. Areal perkebunan yang paling dominan adalah tanaman kelapa (dengan luasan mencapai 44.420,44 ha) diikuti oleh kemiri, kakao cengkeh, aren dan kopi (Heliyanto \& Tenda, 2017).

Tanaman kelapa ini dapat diolah menjadi berbagai macam manfaat, salah satu di antaranya buah kelapa dominan diolah menjadi minyak kelapa secara tradisional. Akan tetapi, dengan adanya mitos bahwa minyak kelapa tidak baik untuk kesehatan maka pemakaian minyak kelapa terpinggirkan dan diganti dengan minyak lainnya. Tetapi dengan diadakannya penelitian, terbukti minyak kelapa mengandung asam lemak yang sangat baik untuk kesehatan, seperti yang diutarakan Dr. E.V. Carandang dalam paper "Coconut Uses And Issues On Its Health And Nutraceutical Benefits" menyebutkan bahwa minyak kelapa dapat digolongkan sebagai pangan fungsional atau Nutraceutical. Maka dari itu, minyak kelapa mulai mendapat perhatian kembali, karena diketahui mempunyai banyak manfaat (Hidayat $d k k$., 2016).

Agroindustri adalah bagian dari agribisnis yang memproses dan mentransformasikan hasil pertanian menjadi barang setengah jadi yang langsung dipakai dan bahan agroindustri yang digunakan dalam proses produksi selanjutnya sehingga dengan adanya industri pengolahan produk pertanian dapat menyediakan kebutuhan bagi konsumen (Pratiwi $d k k$., 2017). Peningkatan produksi pertanian tidak akan memberikan kontribusi bagi pembangunan ekonomi nasional apabila tidak dimanfaatkan sebagai salah satu bahan baku bagi agroindustri. Agroindustri yang berbahan baku tanaman pertanian berperan untuk meningkatkan diversifikasi pertanian bagi masyarakat sehingga dapat meningkatkan selera yang disediakan dalam beberapa bentuk.

Salah satu agroindustri yang dikembangkan di Desa Taekas Kecamatan Miomaffo Timur, Kabupaten Timor Tengah Utara (TTU) adalah agroindustri minyak kelapa murni atau Virgin Coconut Oil (VCO). Menurut Sutarmi \& Rozaline, (2005) Virgin Coconut Oil (VCO) merupakan hasil olahan dari daging buah kelapa segar (Non Kopra) yang dalam pengolahannya tidak melalui proses kimiawi dan tidak menggunakan pemanasan tinggi sehingga minyak yang dihasilkan berwarna bening (jernih) dan beraroma khas kelapa. Komposisi asam lemak tertinggi dalam minyak kelapa murni adalah asam laurat yang berfungsi memberi gizi serta melindungi tubuh dari penyaki menular dan penyakit degeneratif. Menurut Cristianti, (2009) minyak kelapa murni merupakan salah satu produk olahan tanaman kelapa yang berbentuk cair dengan warna yang bening dan berbau khas kelapa serta daya simpan yang lama.

Usaha agroindustri minyak kelapa murni di Desa Taekas dilakukan oleh kelompok wanita tani Fau'ana. Usaha ini mengalami peningkatan produksi minyak kelapa murni yang cukup signifikan dari tahun ke tahun. Adapun peningkatan produksi minyak kelapa murni pada tahun pertama (September 2013) sebanyak 35 botol. Pada tahun 2014 meningkat menjadi 200 botol. Pada tahun 2015 terjadi peningkatan yang cukup besar yakni sebanyak 400 botol, dan pada tahun 2016 menghasilkan 1.600 botol. Menurut Damanik, (2015) pengembangan agribisnis kelapa berperan penting untuk peningkatan produktivitas dan sekaligus peningkatan pendapatan petani. Saat ini kelapa sangat berperan dalam perekonomian sebagai penyedia lapangan tenaga kerja, bahan baku industri dalam negeri dan konsumsi langsung.

Masalah umum yang dihadapi dalam usaha agroindustri minyak kelapa murni oleh kelompok wanita tani Fau'Ana di desa Taekas Kecamatan Miomaffo Timur adalah keterbatasan pengetahuan dan keterampilan dalam mengolah bahan baku, kurangnya pelatihan dan pendampingan dari instansi terkait, kurangnya sarana dan prasarana pendukung yang memadai, keterbatasan sumber daya permodalan, rendahnya sumber daya manusia (SDM). Sebagai langkah awal pemecahan masalah sebagai dukungan untuk pengembangan usaha agroindustri tersebut maka perlu dilakukan kajian dengan topik “Analisis Pendapatan Usaha Agroindustri Minyak Kelapa Murni oleh Kelompok Wanita Tani Fau'ana di Desa Taekas”. Penelitian ini bertujuan untuk mengetahui 1) proses pembuatan minyak kelapa murni; 2) pendapatan agroindustri minyak kelapa murni pada kelompok wanita tani Fau,ana di Desa Taekas Kecamatan Miomaffo Timur Kabupaten TTU.

\section{Metode}

Penelitian dilaksanakan di Desa Taekas Kecamatan Miomaffo Timur Kabupaten TTU sejak bulan November sampai Desember 2017. Pengumpulan data akan dilakukan dengan metode survey, dimana data yang digunakan berupa data primer dan data sekunder. Data primer adalah data-data yang diperoleh melalui wawancara dengan responden berdasarkan daftar pertanyaan yang disiapkan sebelumnya. Sedangkan data sekunder adalah data yang diperoleh dari instansi-instansi terkait.

Penentuan pemilihan sampel dilakukan secara sensus sesuai petunjuk Ating \& Sambas, (2006) yaitu seluruh anggota kelompok wanita tani Fau'ana dengan demikian total pengusaha atau pelaku yang diambil sebagai sampel sebanyak 20 orang.

Untuk mengetahui gambaran usaha minyak kelapa murni di Desa Taekas menggunakan metode analisis deskriptif kualitatif sesuai petunjuk Sugiyono, (2006). Untuk mengetahui pendapatan usaha agroindustri minyak kelapa murni maka digunakan analisis pendapatan sesuai petunjuk (Soekartawi, 1995) dengan rumus $\mathrm{Pd}=\mathrm{TR}-\mathrm{TC}$ dimana $\mathrm{Pd}=$ pendapatan, $\mathrm{TR}=$ total penerimaan, dan $\mathrm{TC}=$ total produksi. Perhitungan biaya produksi yang dikeluarkan oleh petani dihitung sesuai petunjuk Hadisapoetro, (1973).

\section{Hasil dan Pembahasan}

3.1. Gambaran Umum Kelompok Wanita Tani Fau'ana

Kelompok wanita tani Fau'ana berdiri sejak tahun 2012 dengan beranggotakan 6 orang.

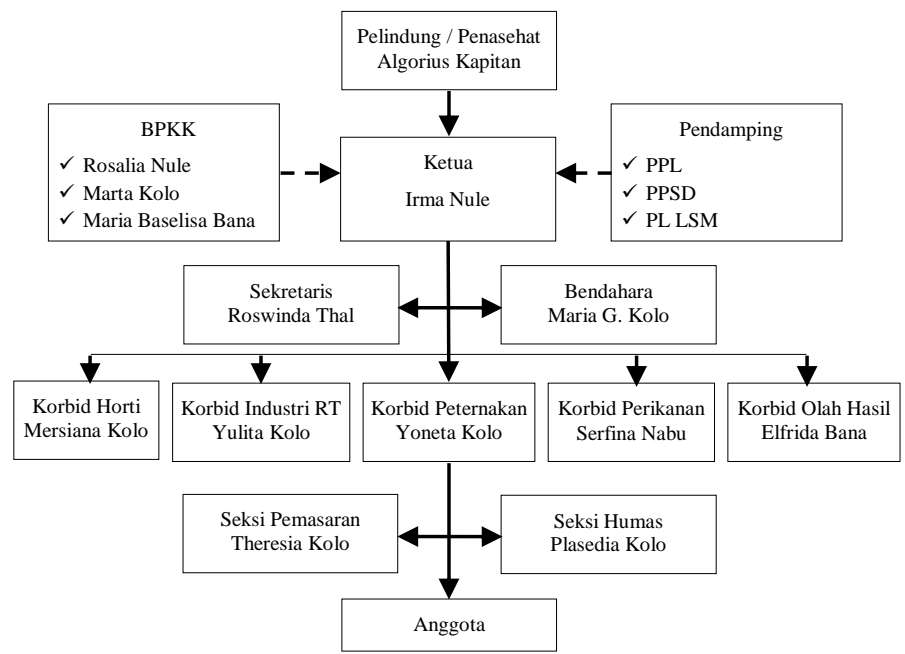

Gambar 1. Struktur Organisasi Kelompok Wanita Tani Fau'ana 
Setelah beroperasi satu tahun terjadi peningkatan pendapatan dan peningkatan jumlah anggota menjadi 20 orang. Kelompok wanita tani Fau'ana dikukuhkan secara resmi pada tanggal 13 Mei 2013. Struktur organisasi kelompok terdiri atas Ketua, Sekretaris, Bendahara, Koordinator Bidang, Seksi dan Anggota. Koordinator bidang terdiri atas bidang hortikultura, industri rumah tangga, peternakan, perikanan, olah hasil. Seksi-seksi terdiri atas seksi hubungan masyarakat dan seksi pemasaran. Kelompok usaha ini didampingi oleh penyuluh (PPL, PPSD, PL LSM). Secara lengkap struktur organisasi kelompok wanita tani Fau'ana dapat dilihat pada Gambar 1.

\subsection{Gambaran Umum Pengolahan Minyak Kelapa Murni}

Berdasarkan hasil pengamatan langsung dan wawancara diketahui bahwa proses pembuatan atau produksi minyak kelapa murni di lokasi penelitian meliputi beberapa tahap pembuatan. Peralatan yang digunakan antara lain parang, pisau, stoples ukuran besar dan sedang, corong, bokor ukuran besar dan sedang, selang plastik, gayung, ember, saringan, lampu 60 Watt dan kabel. Bahan yang dibutuhkan antara lain kelapa kering, gula pasir 1 gelas, gula batu 1 lempeng, kertas karkas dan botol. Pengolahan atau cara pembuatan minyak kelapa murni secara ringkas dilihat pada Gambar 2.

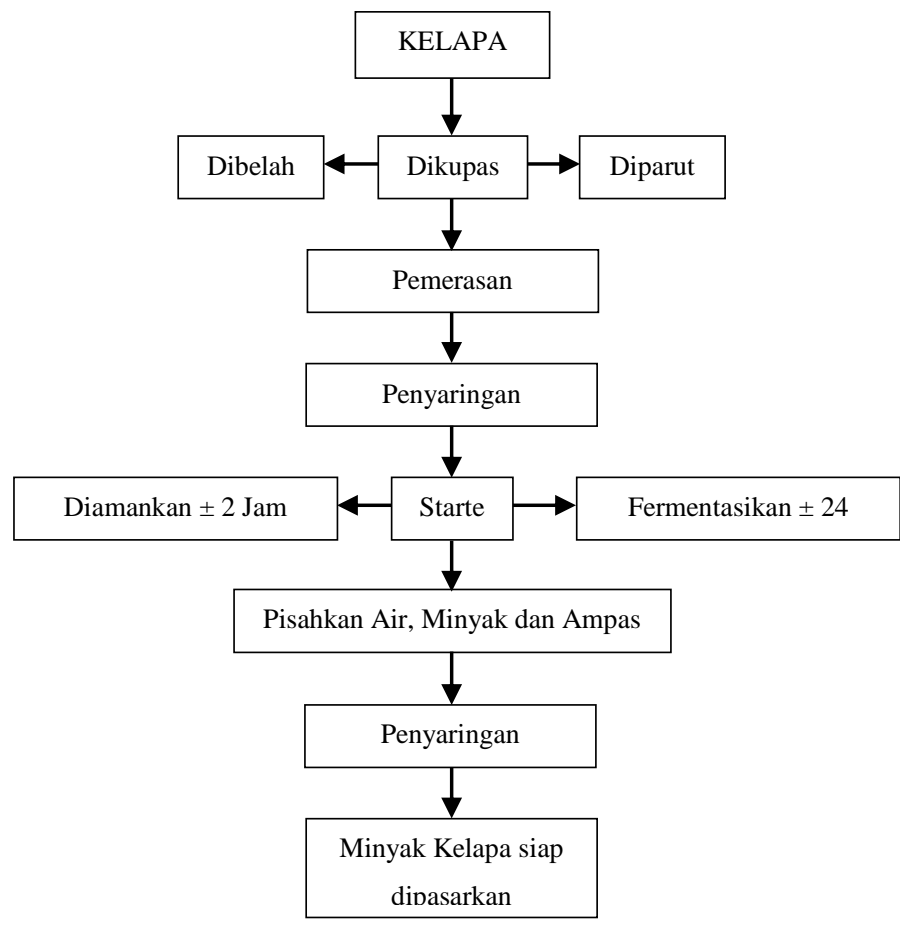

Gambar 2. Bagan Proses Pembuatan Minyak Kelapa Murni

Secara lebih rinci pengolahan atau cara pembuatan minyak kelapa murni yang dilakukan oleh kelompok wanita tani Fau'ana adalah sebagai berikut: a. Kelapa dikupas dengan cara membuang sabut dan tempurungnya kemudian dibersihkan lapisan luar atau kulit arinya dengan menggunakan parang. Buah kelapa dibelah dan dicuci dengan air bersih lalu ditiriskan. Selanjutnya buah kelapa diparut menggunakan mesin parut seperti pada Gambar 3.

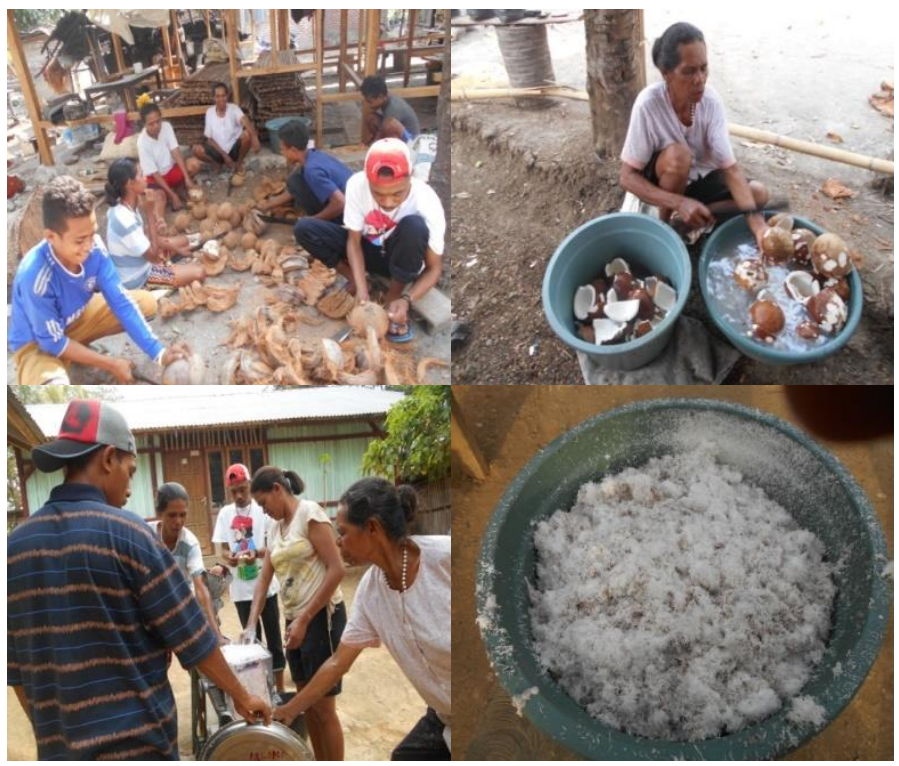

Gambar 3. Pengolahan Buah Kelapa b. Air bersih sebanyak 6 liter dituang ke dalam parutan kelapa, diaduk sampai rata sambil diremas-remas agar santan terkuras keluar. Pemerasan dapat juga dilakukan dengan menggunakan kain atau karung dan alat penjepit. Santan dimasukkan ke dalam stoples, lalu ditutup rapat dan diamankan selama 2 jam hingga terbentuk dua lapisan, yaitu lapisan bawah berupa air dan lapisan atas berupa santan seperti pada Gambar 4 .

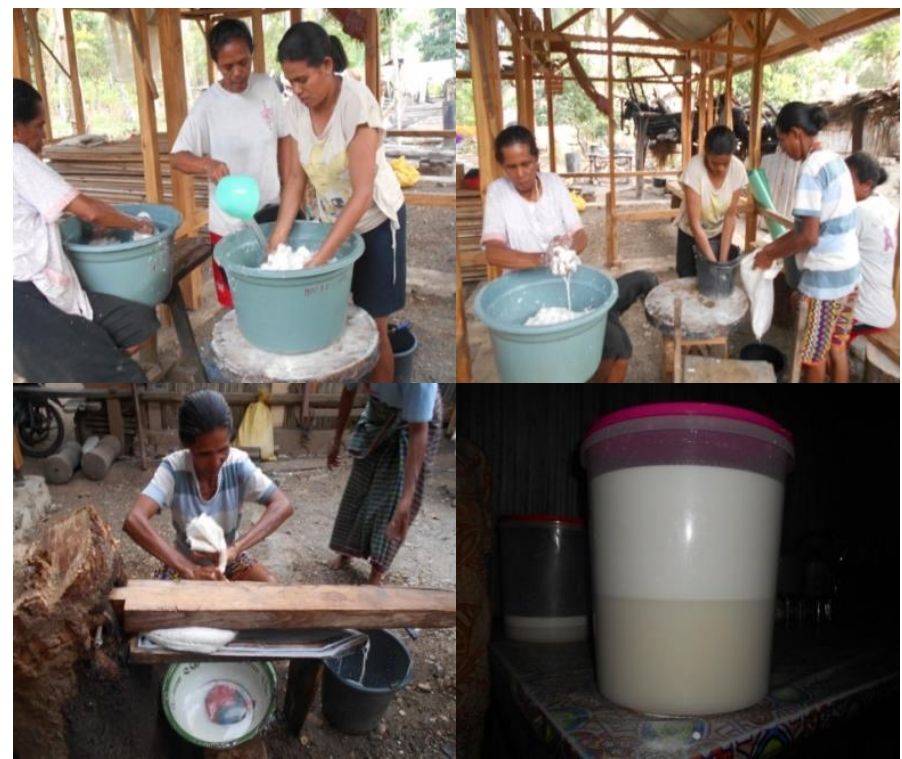

Gambar 4. Pengolahan Santan Kelapa

c. Santan dipisahkan dari air menggunakan selang plastik. Selanjutnya Starte berupa larutan gula pasir dan gula lempeng dituangkan ke dalam santan yang telah dipisahkan sebelumnya. Stoples ditutup rapat dan didiamkan atau fermentasikan selama 24 jam. Setelah 24 jam maka akan terbentuk 3 lapisan, yaitu lapisan bawah berupa air, lapisan tengah berupa minyak dan lapisan atas berupa ampas seperti pada Gambar 5.

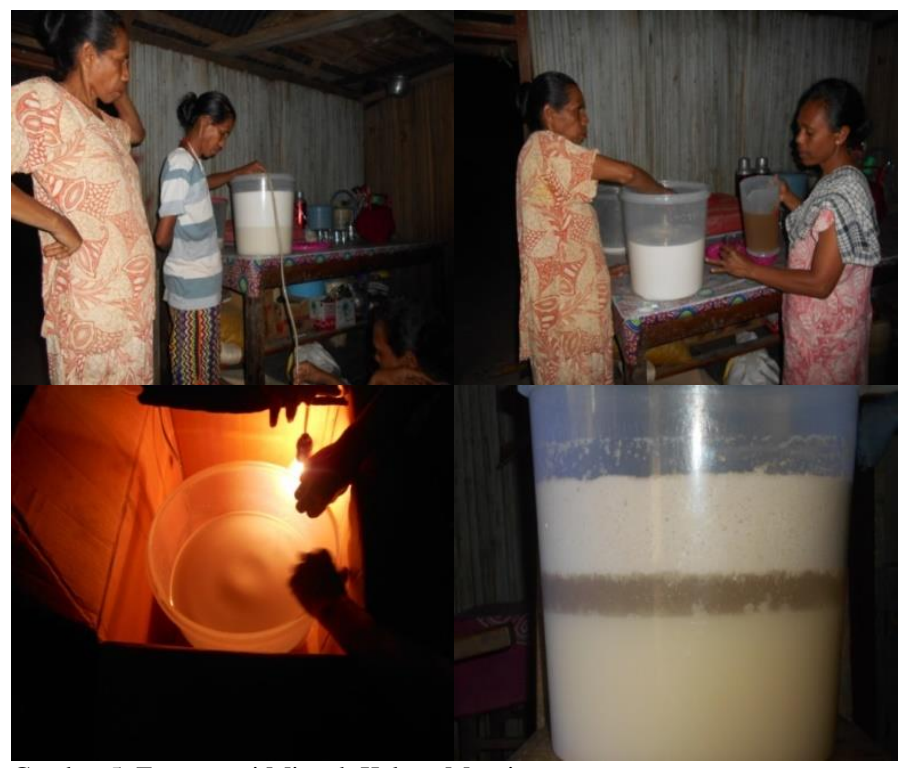

Gambar 5. Fermentasi Minyak Kelapa Murni

d. Minyak dipisahkan dari lapisan air dan ampas menggunakan selang plastik Minyak kemudian disaring menggunakan corong dimana seperempat bagian dari corong dilapisi dengan kertas Karkas dengan tujuan agar minyak yang tersaring memiliki warna jernih. Minyak yang telah tersaring merupakan minyak kelapa murni berkualitas tinggi dengan ciri-ciri antara lain warna minyak bening kristal, tidak berbau dan tidak berasa kecuali aroma khas buah kelapa segar. Sebelum dipasarkan, minyak kelapa murni dikemas dalam botol seperti pada Gambar 6.

\subsection{Produksi Minyak Kelapa Murni dalam Satu Kali Produksi}

Produksi minyak kelapa murni selama tahun 2017 dilakukan sebanyak 12 kali dengan kisaran produksi setiap bulan antara 37 sampai 73 botol atau ratarata 65 botol yang setiap botolnya berisi 85 mil. Produksi terendah pada bulan Maret karena terbatasnya bahan baku pada bulan tersebut dan adanya aktivitas lain dari anggota kelompok. Produksi tertinggi pada bulan Januari, Februari, Mei Juni, Juli, Agustus, September dan Oktober. Jumlah total produksi minyak kelapa murni yakni $91.545 \mathrm{ml}$ yang dikemas dalam 784 Botol. 


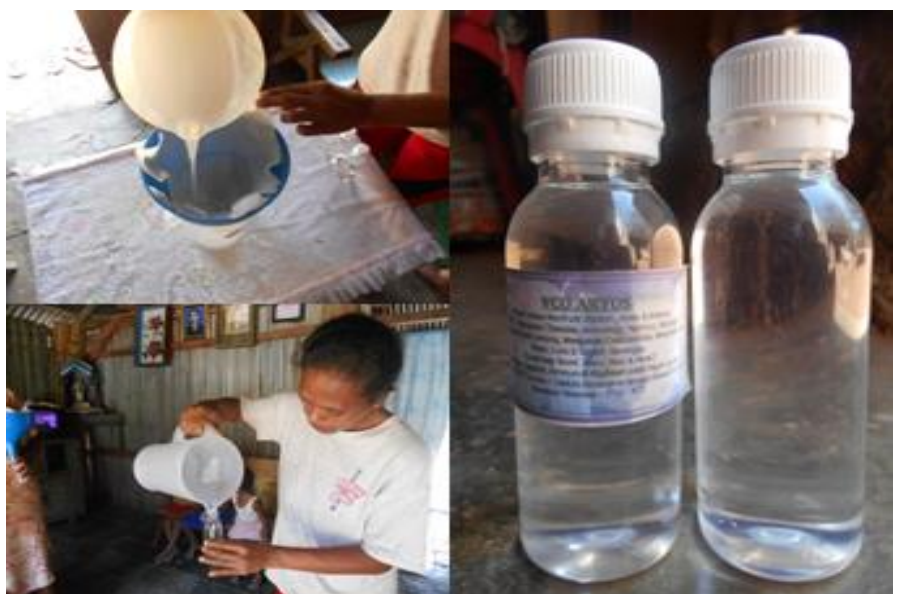

Gambar 6. Penyaringan dan Pengemasan Minyak Kelapa Murni

\subsection{Biaya}

Biaya yang dikeluarkan terdiri atas biaya tetap dan biaya tidak tetap. Biaya tetap terdiri atas bokor, corong, parang, pisau, saringan, selang, gayung, ember, ceret, bola lampu, kabel, stoples. Total biaya tetap sebesar Rp43.750,00. Nilai biaya tetap tergolong kecil karena perhitungannya menggunakan nilai penyusutan, sedangkan peralatan produksi tidak diperhitungkan sebagai biaya karena merupakan hibah dari Dinas Ketahanan Pangan Kabupaten TTU.

Biaya tidak tetap atau biaya variabel terdiri atas biaya bahan baku dan biaya bahan penolong. Biaya bahan penolong terdiri atas gula merah dan gula pasir. Biaya lainnya berupa bahan bakar minyak (bensin), botol, kertas karkas. Total biaya variabel sebesar Rp4.822.000,00. Biaya terbesar untuk pembelian bahan baku yakni sebesar Rp2.254.000,00. Total biaya tetap dan biaya variabel dalam satu kali produksi Rp4.857.750,00.

\subsection{Penerimaan}

Penerimaan sangat tergantung dari pemanfaatan hasil produksi, dari hasil penelitian diketahui bahwa hasil produksi usahatani minyak kelapa murni di Desa Taekas selain dijual juga dikonsumsi sehingga dapat dikatakan usaha tersebut menghasilkan penerimaan. Rata-rata penerimaan sebesar Rp1.625.000,00 dengan kisaran sebesar Rp925.000,00 sampai dengan Rp1.825.000,00. Total penerimaan dalam setahun sebesar Rp19.600.000,00.

\subsection{Pendapatan}

Pendapatan merupakan selisih antara penerimaan dan biaya produksi yang dikeluarkan. Sesuai hasil analisis diketahui bahwa total biaya produksi yang dikeluarkan sebesar Rp4.857.750,00 dan total penerimaan sebesar Rp19.600.000,00 sehingga total pendapatan minyak kelapa murni sebesar Rp14.734.250,00. Rata-rata pendapatan sebesar Rp1.227.850,00 per bulan.

\section{Simpulan}

Agroindustri minyak kelapa murni yang dilaksanakan di Desa Taekas masih dilakukan secara alami, tanpa menggunakan alat modern, secara umum tahapan kegiatan meliputi persiapan alat dan bahan, proses pembuatan, dan pemasaran. Total biaya produksi yang dikeluarkan oleh petani selama satu tahun sebesar Rp4.865.750,00 sedangkan total produksi minyak kelapa murni sebesar 784 botol, sehingga menghasilkan total penerimaan sebesar Rp19.600.000,00. Total pendapatan agroindustri minyak kelapa murni sebesar Rp14.734.250,00 dengan rata-rata pendapatan sebesar Rp1.227.850,00 per bulan.

\section{Pustaka}

Ating, S. \& Sambas, A.M. 2006. Aplikasi Statistika Dalam Penelitian. Bandung: Penerbit Pustaka Setia.

Cristianti, L. 2009. Pembuatan Minyak Kelapa Murni (Virgin Coconut Oil) Menggunakan Fermentasi Ragi Tempe. Laporan Tugas Akhir. Surakarta: Universitas Sebelas Maret.

Damanik, S. 2015. Strategi Pengembangan Agribisnis Kelapa (Cocos nucifera) untuk Meningkatkan Pendapatan Petani di Kabupaten Indragiri Hilir, Riau. Perspektif, 6(2): 94-104.

Hadisapoetro, S. 1973. Pembangunan Pertanian. Yogyakarta: Departemen Ekonomi Pertanian Fakultas Pertanian, Universitas Gadjah Mada.

Heliyanto, B. \& Tenda, E.T. 2017. Varietas Kelapa Dalam Unggul Spesifik Gorontalo. Buletin Palma, 0(38): 73-87.

Hidayat, N., Wignyanto, Sumarsih, S. \& Putri, A.I. 2016. Mikologi Industri. Universitas Brawijaya Press.

Pratiwi, N.A., Harianto, H. \& Daryanto, A. 2017. Peran Agroindustri Hulu dan Hilir Dalam Perekonomian dan Distribusi Pendapatan di Indonesia. Jurnal Manajemen \& Agribisnis, 14(2): 127.

Soekartawi 1995. Analisis Usaha Tani. Jakarta: Universitas Indonesia Press.

Sugiyono, 2006. Metode Penelitian Kuantitatif, Kualitatif dan $R \& D$. Bandung: Alfabeta.
Sutarmi \& Rozaline, H. 2005. Taklukkan Penyakit dengan VCO Virgin Coconut Oil. Jakarta: Penebar Swadaya. 